\title{
Erratum to: Combustion Dynamics of a Propane-Air Gas Mixture When it is Ignited by a Streamer Microwave Discharge
}

\author{
P. V. Bulat ${ }^{a, b}$, L. P. Grachev ${ }^{c, *}$, I. I. Esakov ${ }^{c}$ A. A. Ravaev ${ }^{c}$, and L. G. Severinov ${ }^{c}$ \\ ${ }^{a}$ Ustinov Baltic State Technical University VOENMEKh, St. Petersburg, 190005 Russia \\ ${ }^{b}$ ITMO University, St. Petersburg, 197101 Russia \\ ${ }^{c}$ Moscow Radiotechnical Institute, Russian Academy of Sciences, Moscow, 117519 Russia \\ *e-mail: grachev@mrtiran.ru \\ Received January 27, 2019
}

DOI: $10.1134 / \mathrm{S} 1063784220010296$

The Section FUNDING should read as follows:

This work was financially supported by the Ministry of Education and Science of Russian Federation (agreement no. 14.577.21.0277 (ЭБ 075-15-2019915), unique identifier of applied scientific research is RFMEFI57717X0277).

The original article can be found online at https://doi.org/10.1134/S1063784219100062 